\title{
Regional and global strategies of MNEs: Revisiting Rugman \& Verbeke (2004)
}

\author{
Benjamin Rosa ${ }^{1}$, \\ Philippe Gugler ${ }^{2}$ and \\ Alain Verbeke $3,4,5$ \\ ${ }^{1}$ Faculty of Management, Economics and Social \\ Sciences, Center for Competitiveness of University \\ of Fribourg, University of Fribourg, Bd de Pérolles \\ 90, Fribourg, Switzerland; ${ }^{2}$ Department of \\ Economics, Faculty of Management, Economics \\ and Social Sciences, Center for Competitiveness of \\ University of Fribourg, Chair of Economic and \\ Social Policy, University of Fribourg, Bd de Pérolles \\ 90, Fribourg, Switzerland; ${ }^{3}$ International Business \\ Strategy, McCaig Chair in Management, \\ Haskayne School of Business, University of \\ Calgary, Calgary, AB T2N 1N4, Canada; ${ }^{4}$ Henley \\ Business School, University of Reading, Reading, \\ UK; ${ }^{5}$ Solvay Business School, Vrije Universiteit \\ Brussel, Brussels, Belgium
}

Correspondence:

A Verbeke, International Business Strategy, McCaig Chair in Management, Haskayne School of Business, University of Calgary, Calgary, AB T2N 1N4, Canada e-mail: alain.verbeke@haskayne.ucalgary.ca

Online publication date: 2 July 2020

\begin{abstract}
We describe the extent to which the world's largest companies (in terms of revenues), achieve sales around the globe, and have been able to penetrate markets outside of their home region. We try to answer the following question: Has there been a recent increase in the world's largest firms achieving a global sales orientation, meaning a balanced, global distribution of sales? Rugman \& Verbeke (2004) found that few of the 2002 Fortune Global 500 (Fortune Magazine 2002) firms, accounting for over $90 \%$ of the world's stock of FDI, actually had a global sales orientation. A majority of multinational enterprises (MNEs) were home-region oriented, suggesting that much work on corporate globalization was normative, rather than accurately describing reality. We present the equivalent data for the 2017 Fortune Global 500 (Fortune Magazine 2017) list. Our data confirm that many large firms are still home-region oriented, but to a lesser extent than before, with 36 MNEs (up from only nine in the 2002 list), now having widely distributed sales across the world's core economic regions. The question arises whether this relative increase in the number of MNEs with a global sales orientation holds any normative value for the firms that presently do not have such a sales distribution.
\end{abstract}

Journal of International Business Studies (2020) 51, I045-1053. https://doi.org/10.1057/s41267-020-00347-5

\section{INTRODUCTION}

Rugman and Verbeke (2004: 3) found that few of the world's 500 largest firms, though representing over $90 \%$ of the overall stock of foreign direct investment (FDI), were companies with a global sales orientation. Their criterion of balanced sales distribution across three, highly developed economic regions (North America, Europe and Asia) is clearly just one (imperfect) proxy for corporate globalization. But this criterion does at least provide an indication of a firm's market success with customers across home-region borders, into host regions that typically have large incumbents in the same industry (Verbeke, Coeurderoy \& Matt, 2018). Further studies conducted by Rugman and his co-authors, based on assets, also found evidence on the limits of corporate globalization (Collinson \& Rugman, 2008; Rugman \& Brain, 2003; Rugman \& Verbeke, 2008a; Oh \& Rugman, 2014).

These findings led to a debate on the importance of MNE geographic orientation, especially in terms of inter-regional sales and asset distribution, and on the meaning of corporate 
globalization. The late John Dunning (1997: 34) had earlier defined a global firm as follows:

\begin{abstract}
“...a typical global firm will own or control subsidiaries, and engage in value-added business alliances and networks in each continent and each major country...it will sell its goods and services in each of the main markets of the world."
\end{abstract}

Rugman and Verbeke (2004) described just one facet of this complex phenomenon of corporate globalization, but the main observation based on the narrow, sales-distribution criterion, was that the level of corporate globalization had been vastly exaggerated in academic research and popular media (Verbeke et al., 2018). In the present contribution, we update Rugman and Verbeke's analysis that was based on data published in the 2002 Fortune Global 500 (Fortune Magazine, 2002), using information published 15 years later. We first briefly discuss the methodology, results and limitations of Rugman and Verbeke's study. We then adopt the same approach as used in that study to analyze data from the Fortune Global 500 list of 2017 , and assess whether the level of corporate globalization, based on the narrow criterion of geographic sales orientation, has changed over time.

\section{INSIGHTS FROM RUGMAN \& VERBEKE (2004)}

As noted above, Rugman and Verbeke (2004) based their research on sales data of the 2002 Fortune Global 500 (Fortune Magazine, 2002). The authors argued that the distribution of sales around the world represents a genuine performance measure at the downstream level, answering the simple question whether firms can emulate their domestic and home region success in distant environments (see also Rugman \& Verbeke, 2005). Extending Ohmae (1985), they considered three broad regions to assess a firm's geographic orientation, namely North America, Europe and Asia. This is the socalled Triad, where most innovations across industries originate; where most lead markets for new, knowledge intensive products can be found; and where in many instances, large rivals in the same industry have their home-base. Most of the world's largest firms also have the bulk of their sales in these three regions (Rugman \& Verbeke, 2004: 4).

The authors identified four MNE geographic orientations: home-region oriented, bi-regional oriented, host-region oriented, and global. Homeregion oriented means that a firm has at least 50\% of its sales concentrated in its home market of the
Triad. The 50\% threshold was used because this percentage suggests that the firm has a dominant position in its home region markets. It will typically also have most of its strategic decisions strongly influenced by what unfolds in the home-region market, representing the majority of its revenues.

The second category, bi-regional orientation, includes firms that achieve less than $50 \%$ of their sales in their home region, and at least $20 \%$ of their sales in another region of the Triad. According to Rugman and Verbeke, the $20 \%$ threshold in a host region demonstrates successful market penetration in another leg of the Triad, in terms of emulating home region success at the customer end. An MNE must have more than $50 \%$ of its sales in a host region of the Triad, for it to be classified as hostregion oriented. In most cases, this reflects the presence of non-location bound FSAs embedded in products and services that become more popular in a large distant market than they are at home, sometimes because the home region market has a larger number of rivals with similar offerings. Finally, the global orientation status means that an MNE has achieved at least $20 \%$ of its sales in each of the three legs of the Triad, but less than $50 \%$ of its sales in any of these three regions. Achieving at least $20 \%$ of sales in each Triad region demonstrates -and we do agree this is a normative perspectivethat a firm has been able to deploy successfully its firm specific advantages (FSAs) throughout the world, i.e., that it truly commands non-location bound FSAs (Rugman \& Verbeke, 2004:7). Such global sales orientation can reasonably be considered as one tangible expression of a successful global strategy, even though corporate globalization entails much more than success on this measure alone (Verbeke et al., 2018).

Among the MNEs listed in the 2002 Fortune Global 500 (Fortune Magazine, 2002), 380 firms had detailed sales data available in their annual reports or other publications. These 380 firms represented $79.2 \%$ of the total revenues of the Global 500, with an average sales volume of 29.2 billion US dollars (Rugman \& Verbeke, 2004: 5). Only 365 of the 380 firms had data that permitted a region-based unbundling of their sales according to the above categorization, see Table 1 . The remaining 135 companies were not included in the study, and some of these were actually not MNEs, but large companies with a clear domestic focus.

Rugman and Verbeke (2004) identified 320 firms $(87.7 \%)$ with at least $50 \%$ of their sales in their home region of the Triad, meaning a home-region 
Table 1 Classification of the World's Largest Firms - Fortune Global 500 List in 2002

\begin{tabular}{lll}
\hline Geographic orientation & Number of MNEs & \% of 365 firms \\
\hline Global & 9 & 2.5 \\
Home-regional & 320 & 87.7 \\
Bi-regional & 25 & 6.8 \\
Host-regional & 11 & 3.0 \\
No/Insufficient data & 135 & - \\
Total & 500 & 100
\end{tabular}

Source: Based on Rugman \& Verbeke (2004)

orientation. Twenty-five MNEs (6.8\%) were biregional, and 11 MNEs (3\%) had more than 50\% of their sales in a foreign market and were hostregion oriented. The remaining nine MNEs-2.5\% were classified as having a global orientation. The group of globally oriented MNEs included IBM, Sony, Philips, Nokia, Intel, Canon, Coca-Cola, Flextronics and Moët Hennessy-Louis Vuitton (LVMH).

The authors concluded that most large MNEs did not have a global orientation of their revenues, and that the world was "semi-globalized" (Rugman \& Verbeke, 2004: 17). But rather than interpreting this outcome as strategy failure, they viewed it as largely a deliberate choice: Given their resource reservoirs, many MNEs have a preference for conducting regionally-based activities. Here, the importance of each region in a firm's revenue streams likely results from a careful cost-benefit assessment of the transferability, deployability and exploitation potential of its FSAs across geographic space. That is: “...regional strategies of MNEs are embedded in - and co-evolve with - the broader competitive, organizational and institutional contexts at the regional level" (Rugman \& Verbeke, 2004: 16). The authors did recognize that regions change over time and could therefore become the locus of new opportunities for MNEs to pursue projects that meet financial (or other) performance targets.

Rugman and Verbeke (2008a: 398) acknowledged that their 2004 study "did not address explicitly the industry effect, especially the distinction between manufacturing and services". In their follow-up paper, they did address this distinction and found a difference between service firms and manufacturing companies. Service MNEs were found to have an average of $83.9 \%$ of their sales in the home region, whereas manufacturing MNEs had a home-region sales average of only 65.6\%: "Goods manufacturing and services provision will, overall, show similar tendencies in terms of being largely home region-oriented rather than global, but the magnitude of globalization (in terms of sales and asset dispersion across the Triad) will be significantly lower in services" (Rugman \& Verbeke, 2008a: 401). The initial observation therefore remained valid; there were only a few firms with a global orientation (whether in terms of assets or sales), in both the services and manufacturing industries (Rugman \& Verbeke, 2008a).

Dunning, Fujita and Yakova (2007) agreed that sales revenues do constitute a proxy for the geographic distribution of economic activity, but they viewed the focus on region-based sales data to assess MNE strategy as fraught with problems. For example, these authors criticized the fact that Rugman and Verbeke included in home-region sales not only the sales realized in foreign countries within the home region, but also the sales achieved in the MNE's home country itself. As a counter argument, it is correct that home-country sales are not part of international business activity, but at the same time a home-region strategy often complements the conventional home-country approach to strategy. The main point here is that the joint effect of the various components of distance (geographic, economic, cultural and institutional), i.e., the impact of compounded distance within a region often does not seriously affect the transferability, deployability and economic exploitation potential of the MNE's FSA. These FSAs are therefore largely non-location bound within the region (at least relative to hostregional expansion where any novel resource bundling of extant FSA reservoirs is often more difficult to achieve).

It should, however, be acknowledged that the home-country effect often does matter: a company located in the United States might have a lower propensity than a Canadian firm to seek sales in foreign markets, even in the home region. The reason can be that efficient scale across the value chain can be achieved by serving the home market alone, or that this home market provides institution-based advantages to domestic 
incumbents. An increase in the overall share of home-region sales could even result from a simultaneous rise in home country revenues and a decline in sales in other countries in the region. Dunning et al. (2007) therefore argued that firmlevel data be considered together with countrylevel data, so as to qualify better the analysis at hand, and that variables other than sales should be included in the analysis. Oh and Rugman (2014) did unbundle domestic sales and other homeregion sales: Their analysis uncovered that homeregion sales outside of the domestic market were on average as large as those achieved in each of the host Triad markets.

Osegowitsch \& Sammartino (2008: 184-186) disagreed with the view that globalization is a myth, and criticized the thresholds of $50 \%$ and $20 \%$ to classify firms as home-regional, bi-regional, hostregional or global. They felt that these sales thresholds were unnecessarily restrictive. When relaxing Rugman and Verbeke's (2004) threshold percentages, Osegowitsch and Sammartino (2008) found a substantially higher number of firms with a supposedly global or bi-regional sales orientation. The legitimate question of course arises whether having, for example, $10 \%$ of sales in a host region, meaning less than one fifth of the sales achieved in the home region, can reasonably be used as a proxy for successful corporate globalization. In addition, in the context of real-world, strategic decision making, the question does arise whether a host region representing $10 \%$ of overall sales, would elicit the same strategic attention from the top management team and board of directors, as a region representing $20 \%$. Reasonable observers would probably agree that this is ultimately an empirical question, and one that should be answered by interacting with actual members of top management teams and board members of large firms.

These authors also suggested that analysis of geographic orientation should take into account industry specificities. As mentioned above, Rugman and Verbeke (2008a) addressed this issue in the manufacturing versus services context, while also emphasizing that most firms listed in the Fortune Global 500 are diversified companies, active in several industries (Rugman \& Verbeke, 2008b).

As a final point on the limitations of this type of geographic-region based analysis, it should be acknowledged that the use of particular percentage thresholds can be fine-tuned by making adjustments for regional GDP numbers. For example, Asia now has a substantially higher regional product than North America. Based on this metric alone, one would expect the sales volume of an European MNE in Asia to be higher than its sales volume in North America. In addition, in some sectors (such as the large civil aircraft industry), it might be reasonable to acknowledge explicitly the "rest of the world" as a fourth region, or even to take into account explicitly a larger number of regions, because of the truly global distribution of purchasing inputs and consumption. The counterargument to the above is that the Triad regions did, and still do, represent the home bases of most large, technology- and brand-name based MNEs in the world.

\section{GLOBALIZATION IN THE 2017 FORTUNE GLOBAL 500 (FORTUNE MAGAZINE, 2017)}

The 2017 Fortune Global 500 (Fortune Magazine, 2017) list includes 478 companies (95.6\%) with corporate head offices in the Triad regions, see Table 2. These data confirm the preponderance of the Triad as the home base of the majority of the world's largest MNEs, whereby the firms from Oceania could have been considered as being part of the broad Asia-Pacific region, and therefore part of the Asian leg of the Triad.

As was the case in Rugman and Verbeke (2004), we hand-collected the annual reports and financial statements of the enterprises listed in the 2017 Fortune Global 500 (Fortune Magazine, 2017) (data for 2016). We searched each annual report for information on the revenues by geographic region. In many instances, we were able to find the required information per geographic segment and entered it directly into our database. In some cases, the information was only partially available: typically, the home country share in total sales would be provided, but details on foreign sales would be insufficient for a precise, region-based distribution. On the positive side, when this was the case, the percentage of foreign sales ranged between $1 \%$ and $15 \%$, thus reflecting both a home-country and home-region orientation. In some instances, the company reports even indicated explicitly that all activities (100\%) took place in the firms' respective home regions. For example, CVS Health, a North American company ranked 14th in the Fortune Global 500 - with 177 billion dollars in revenues operates only in North America.

The above allowed including 386 firms (or 77\%) in our analysis. We classified these firms according to their geographic orientation: home-regional, biregional, host-regional and global. Among the 
Table 2 Regional Home Base Distribution of the 2017 Fortune Global 500 (Fortune Magazine, 2017)

\begin{tabular}{lllllll}
\hline North America & Europe & Asia & South America & Middle East & Africa & Oceania \\
\hline 141 & 140 & 197 & 10 & 3 & 2 & 7 \\
\hline
\end{tabular}

Source: Fortune Global 500 (2017)

Table 3 Classification of the World's Largest Firms - Fortune Global 500 List in 2017

\begin{tabular}{lll}
\hline Geographic orientation & Number of MNEs & \% of 365 firms \\
\hline Global & 36 & 9.3 \\
Home-regional & 286 & 74.1 \\
Bi-regional & 39 & 10.1 \\
Host-regional & 25 & 6.5 \\
No/Insufficient data & 114 & \\
Total & 500 & 100 \\
\hline
\end{tabular}

Source: Authors' calculations

remaining 114 firms, there were 79 that did not provide any geographic segment data on sales, and 35 with some geographic distribution data on revenues, but insufficient for classifying the firm into one of Rugman and Verbeke's four categories.

Table 3 shows the number of firms in each category. We found 36 MNEs (or 9.3\% of the 386 firms with sufficient information) that could be categorized as firms with a global orientation, see Table 4. A total of 286 MNEs (or 74.1\%) remained home-region oriented. Within this set, a small number of companies narrowly missed earning global sales orientation status because they earned slightly over $50 \%$ of their revenues from their home region. These include Siemens $52 \%$ in the home region of Europe, $20 \%$ in North America, and $19.5 \%$ in Asia); Robert Bosch (53\% in the home region of Europe, 28\% in Asia, and 19\% in North America); Johnson \& Johnson (53\% in the home region of North America, 22\% in Europe and 17\% in Asia) and Facebook (50\% in the home region of North America, 24\% in Europe, and 16\% in Asia).

Finally, a total of 39 MNEs earned bi-regional status and 25 MNEs had a host-region orientation. As noted above, Rugman and Verbeke's classification of the firms in four categories could be viewed as somewhat underestimating the number of firms with a global sales orientation, since the Middle East, Latin America and Africa are excluded from the analysis. For example, several bi-regionally oriented companies were close to achieving a global sales orientation, but did not achieve this status because of sales outside of the Triad regions. These cases include, among others, Samsung (28\% in the home region in Asia, 34\% in North America, and $19 \%$ in Europe); Johnson \& Johnson (53\% in the home region of North America, 22\% in Europe, and $17 \%$ in Asia); Hon Hai Precision Industry (19.5\% in the home region of Asia, 31\% in North America, and $33 \%$ in Europe); Sony (47\% in the home region of Asia, $18.6 \%$ in North America and 24\% in Europe), and China Cosco Shipping (35\% in Asia, $27 \%$ in North America and $18.7 \%$ in Europe).

As noted above, the number of MNEs with a global sales orientation quadrupled from nine MNEs in 2002 to 36 in 2017. The number of MNEs with a bi-regional sales orientation also increased, from 25 to 39 , and the number of host-region oriented firms rose from 11 to 25 MNEs. If much more liberal criteria were applied, requiring only $10 \%$ of sales in two host regions, and not applying the "below 50\% threshold" of sales in the home region to achieve a global sales orientation, there would be 96 globally oriented MNEs, and 100 biregionally oriented ones in the Fortune Global 500 firms. But as we asked in the previous section, do such liberal criteria actually provide any useful information on corporate globalization?

\section{CONCLUSION}

We reassessed the geographic orientation of the Fortune Global 500 firms, 15 years after Rugman and Verbeke observed that only few MNEs could reasonably be identified as having a global sales orientation, based on the distribution of their revenues across the main economic regions of the world. When applying the original methodology, the general observation from 15 years ago still 
Table 4 Global MNEs in the 2017 Fortune Global 500 (Fortune Magazine, 2017)

\begin{tabular}{|c|c|c|c|c|c|c|}
\hline $\begin{array}{l}\text { Rank in Fortune Global } \\
500\end{array}$ & Company name & $\begin{array}{l}\text { Revenues (US \$ } \\
\text { million) }\end{array}$ & Home Region & $\begin{array}{l}\text { North America } \\
(\%)\end{array}$ & $\begin{array}{l}\text { Europe } \\
(\%)\end{array}$ & $\begin{array}{l}\text { Asia } \\
(\%)\end{array}$ \\
\hline 7 & Royal Dutch Shell & 233,591 & Europe & 21,04 & 34,92 & 35,58 \\
\hline 9 & Apple & 215,639 & $\begin{array}{l}\text { North } \\
\text { America }\end{array}$ & 40,17 & 23,16 & 30,34 \\
\hline 17 & Daimler & 169,483 & Europe & 29,34 & 41,38 & 23,20 \\
\hline 51 & BMW Group & 104,130 & Europe & 20,72 & 47,07 & 28,76 \\
\hline 53 & Trafigura Group & 98,098 & Europe & 22,00 & 26,00 & 29,00 \\
\hline 77 & Hyundai Motor (Yen) & 80,701 & Asia & 29,57 & 22,64 & 46,19 \\
\hline 80 & IBM & 79,919 & $\begin{array}{l}\text { North } \\
\text { America }\end{array}$ & 46,94 & 30,99 & 21,66 \\
\hline 97 & Procter \& Gamble & 71,726 & $\begin{array}{l}\text { North } \\
\text { America }\end{array}$ & 45,00 & 23,00 & 24,00 \\
\hline 149 & Unilever & 58,292 & Europe & 32,45 & 24,97 & 42,58 \\
\hline 153 & United Technologies & 57,244 & $\begin{array}{l}\text { North } \\
\text { America }\end{array}$ & 38,00 & 28,00 & 20,00 \\
\hline 167 & Roche Group & 53,427 & Europe & 43,58 & 27,37 & 21,10 \\
\hline 184 & Novartis & 49,436 & Europe & 35,28 & 35,20 & 21,52 \\
\hline 207 & Kia Motors & 45,425 & Asia & 32,47 & 29,62 & 36,69 \\
\hline 218 & Swiss $\operatorname{Re}$ & 43,743 & Europe & 45,45 & 32,88 & 21,67 \\
\hline 224 & Lenovo Group & 43,035 & Asia & 30,00 & 26,00 & 28,00 \\
\hline 232 & Christian Dior & 42,113 & Europe & 26,00 & 29,00 & 33,00 \\
\hline 233 & Coca-Cola & 41,863 & $\begin{array}{l}\text { North } \\
\text { America }\end{array}$ & 46,46 & 33,11 & 24,09 \\
\hline 261 & ZF Friedrichshaffen & 38,888 & Europe & 27,00 & 48,00 & 22,00 \\
\hline 262 & Caterpillar & 38,537 & $\begin{array}{l}\text { North } \\
\text { America }\end{array}$ & 45,53 & 24,20 & 21,42 \\
\hline 311 & $A B B$ & 33,823 & Europe & 22,00 & 46,00 & 32,00 \\
\hline 344 & Canon & 31,271 & Asia & 28,33 & 26,86 & 44,82 \\
\hline 354 & $\begin{array}{l}\text { Mizuho Financial } \\
\text { Group }\end{array}$ & 30,390 & Asia & 33,30 & 20,51 & 46,15 \\
\hline 358 & $3 \mathrm{M}$ & 30,109 & $\begin{array}{l}\text { North } \\
\text { America }\end{array}$ & 40,48 & 20,47 & 29,38 \\
\hline 364 & Mazda Motor & 29,665 & Asia & 27,50 & 23,50 & 31,70 \\
\hline 372 & Royal Philips & 29,003 & Europe & 36,05 & 28,76 & 30,89 \\
\hline 376 & L'Oreal & 28,572 & Europe & 24,80 & 25,30 & 36,90 \\
\hline 385 & Schlumberger & 27,810 & $\begin{array}{l}\text { North } \\
\text { America }\end{array}$ & 23,97 & 26,43 & 33,39 \\
\hline 396 & Schneider Electric & 27,307 & Europe & 28,00 & 27,00 & 27,00 \\
\hline 410 & Avnet & 26,219 & $\begin{array}{l}\text { North } \\
\text { America }\end{array}$ & 39,76 & 29,79 & 30,45 \\
\hline 434 & DuPont & 24,594 & $\begin{array}{l}\text { North } \\
\text { America }\end{array}$ & 42,34 & 23,33 & 23,59 \\
\hline 442 & Danone & 24,267 & Europe & 20,05 & 39,52 & 40,42 \\
\hline 452 & Arrow Electronics & 23,825 & $\begin{array}{l}\text { North } \\
\text { America }\end{array}$ & 48,03 & 28,43 & 23,55 \\
\hline 453 & Heraeus Holding & 23,793 & Asia & 26,00 & 30,00 & 42,00 \\
\hline 454 & Compal Electronic & 23,773 & Asia & 38,50 & 27,10 & 31,60 \\
\hline 462 & Michelin & 23,120 & Europe & 26,25 & 32,18 & 24,88 \\
\hline 466 & Astra Zeneca & 23,002 & Europe & 36,18 & 32,30 & 27,84 \\
\hline
\end{tabular}

holds: Only a small number of MNEs, namely 36 out of 386 firms with available data, or $9.3 \%$, have a global orientation.
This modest number does represent a quadrupling of the 9 firms with a global orientation, reported in Rugman and Verbeke (2004). The bi- 
regional and host region oriented groups also increased in importance. As the mirror image of these results, the share of home-region MNEs declined from $87.7 \%$ to $74.1 \%$. These results suggest, though based on only a single and very imperfect proxy, that corporate globalization has been on the rise among the world's largest firms.

However, a dominant home-region sales orientation does remain the strategic outcome for three quarters of the world's largest companies, unless the concept of corporate globalization at the downstream end is watered down, and firms with more than $50 \%$ of their sales in their home region and achieving as little as $10 \%$ of sales in two host regions were also identified as global. But how exactly is achieving less than one fifth of homeregion sales in other core economic regions of the world an expression of global corporate success for a "Global 500" company? Semi-globalization thus still prevails, and the question arises to what extent the recent anti-globalization sentiments expressed through many ongoing institutional shifts across the world, will hinder or possibly even reverse the observed trend toward greater corporate globalization (Colantone \& Stanig, 2018; Rodrik, 2018; Petricevic \& Teece, 2019; Witt, 2019).

Acknowledging that the data we presented are rudimentary and only indicative, they do suggest that analysis of regional strategy, beyond the country-level but below the global level, does remain important subject matter for international business scholarship (Verbeke \& Asmussen, 2016). A new and rich scholarly literature is being developed in this realm, which will hopefully contribute to counteracting naïve and ill-founded narratives on the substance and performance implications of corporate globalization. Importantly, most recent studies do point to a liability of regional foreignness or regional outsidership and to the continued region-boundedness of the FSAs of many large, internationally operating firms.

Rugman and Verbeke (2008c) and Verbeke and Kano (2016) among others have described in some detail the possible content and managerial implications of regional MNE strategies. The most important insights include the following. First, from a micro-foundational perspective, senior managers do tend to overestimate the non-location bound nature of their FSAs when entering host regions, which often leads to a divorce between the talk on corporate globalization and actual performance metrics, whether in terms of market penetration, financial performance or any other measure of success. Second, adapting international strategy to regional characteristics may entail complex types of asset bundling, and more generally resource recombination. Well-designed and properly executed regional asset-bundling processes appear to be the key to achieving success in host regions, and thereby the conduit to higher corporate globalization, even for firms with supposedly strong upstream or downstream capabilities.

\section{Postscript on Regional Strategy Research in the Post-Pandemic Era}

The COVID-19 pandemic as a global disruption, will potentially have significant impacts on the geographic orientation and broader regional strategies of many Fortune Global 500 companies. We predict, somewhat speculatively, three impacts that may be worth studying by regional strategy scholars.

First, one possible effect of the global pandemic, which uncovered many hidden vulnerabilities in supply chains, is the increased reshoring by Western MNEs of economic activities presently conducted in China and other host-region locales, because of macro-level institutional fractures with micro-level cascading effects. For example, the number of 'regional factories' focused on the home region, rather than Buckley-type 'global factories' will likely increase. The predicted outcome is that fewer firms will have a global sales orientation in the future than is the case today.

Second, regional supply chains will gain in importance in many industries at the expense of more global ones, to reduce the challenge of imperfect information and information processing (bounded rationality), and that of contracting parties and broader stakeholders not making good on their commitments (bounded reliability). If network mapping, focused on how specific actors and units in supply chains might trigger system-wide disruptions, identifies unacceptable vulnerabilities in inter-regional supply chains, organizational adaptation will ensue. Organizationally, even global firms will then likely reduce the number and the magnitude of inter-regional linkages. They will introduce more intra-regional coordination and control mechanisms, and give more autonomy to their units in host regions. The need for more regional organization will be a powerful counterweight to the forces of digitalization, which were supposed to drive neo-global organizational forms, and facilitate more centralized coordination and control. 
Third, when selling or operating in quasi-hostile regions with macro-level institutional fractures visà-vis the home region, MNEs that have decided to remain active in these regions may want to give new roles to reliable partners, especially in 'sensitive' industries, to keep their social license to operate and to facilitate asset bundling, and more generally, novel resource combination. 'Sensitive' industries are different from 'strategic' industries. Defending the latter has a clear economic rationale such as the expectation that dynamic economies of scale and technological leadership will be gained, even though poor policy execution can easily drive inefficiencies and therefore lead to failure. In contrast, 'sensitive' industries do not require a substantive economic rationale for discriminating against firms from other Triad regions. Such discrimination may have its roots in the spheres of public health and safety, security, and even modern populism, whereby a nation supposedly must nurture home-grown firms that are active in 'heritage sectors'. One response of MNEs to such sentiments and related hostile policy measures is to identify host-regional partners, who can support enduring insidership, partly through intelligence gathering

\section{REFERENCES}

Arregle, J. L., Miller, T. L., Hitt, M. A., \& Beamish, P. W. 2018. The role of $\mathrm{MNEs}^{\prime}$ internationalization patterns in their regional integration of FDI locations. Journal of World Business, 53(6): 896-910.

Colantone, I., \& Stanig, P. 2018. Global competition and Brexit. American Political Science Review, 112(2): 201-218.

Collinson, S., \& Rugman, A. M. 2008. The regional nature of Japanese multinational business. Journal of International Business Studies, 39(2): 215-230.

Demirbag, M., Glaister, K. W., \& Sengupta, A. 2020. Which regions matter for MNEs? The role of regional and firm level differences. Journal of World Business, 55(1): 101026.

Dunning, J. 1997. Alliance capitalism and global business. London: Routledge.

Dunning, J. H., Fujita, M., \& Yakova, N. 2007. Some macro-data on the regionalisation /globalisation debate: a comment on the Rugman/Verbeke analysis. Journal of International Business Studies, 38(1): 177-199.

Fortune Magazine-Fortune Global 500. 2002. https://fortune. com/global500/2001/.

Fortune Magazine-Fortune Global 500. 2017. http://fortune. com/global500/list/.

Hillemann, J., Verbeke, A., \& Oh, W. Y. 2019. Regional integration, multinational enterprise strategy and the impact of country-level risk: The case of the EMU. British Journal of Management, 30(4): 908-925.

Kim, M., Lampert, C. M., \& Roy, R. 2020. Regionalization of R\&D activities:(Dis) economies of interdependence and inventive performance. Journal of International Business Studies (forthcoming).

Kim, H., Wu, J., Schuler, D. A., \& Hoskisson, R. E. 2020. Chinese multinationals' fast internationalization: Financial performance advantage in one region, disadvantage in another. Journal of International Business Studies (forthcoming). and processing, and partly through providing legitimacy. The conventional international business prediction is likely to hold that cooperative arrangements with host-region partners will be preferred over internalization in the face of exogenous, uncontrollable risks arising at the macrolevel.

\section{NOTES}

${ }^{1}$ Among the 22 companies headquartered outside of the Triad, 13 MNEs also have more than $50 \%$ of their sales in a region located outside the Triad (typically their own home region).

${ }^{2}$ This new literature includes, inter alia, the following studies: Schotter, Stallkamp \& Pinkham (2017); Arregle, Miller, Hitt \& Beamish (2018); Mohr, Batsakis \& Stone (2018); Hillemann, Verbeke \& Oh (2019); Oh, Kim \& Chin (2019); Kim, Lampert \& Roy (2020); Demirbag, Glaister \& Sengupta (2020) and Kim, Wu, Schuler \& Hoskisson (2020).

Mohr, A., Batsakis, G., \& Stone, Z. 2018. Explaining the effect of rapid internationalization on horizontal foreign divestment in the retail sector: An extended Penrosean perspective. Journal of International Business Studies, 49(7): 779-808.

Oh, C. H., Kim, M., \& Shin, J. 2019. Paths and geographic scope of international expansion across industries. International Business Review, 28(3): 560-574.

Oh, C. H., \& Rugman, A. 2014. The dynamics of regional and global multinationals, 1999-2008. The Multinational Business Review, 22(2): 108-117.

Ohmae, K. 1985. Triad power. New York: The Free Press.

Osegowitsch, T., \& Sammartino, A. 2008. Reassessing (home-) regionalisation. Journal of International Business Studies, 39(2): 184-196.

Petricevic, O., \& Teece, D. J. 2019. The structural reshaping of globalization: Implications for strategic sectors, profiting from innovation, and the multinational enterprise. Journal of International Business Studies, 50(9): 1487-1512.

Rodrik, D. 2018. Populism and the economics of globalization. Journal of International Business Policy, 1(1-2): 12-33.

Rugman, A. M., \& Brain, C. 2003. Multinational enterprises are regional, not global. Multinational Business Review, 11(1): 3-12.

Rugman, A., \& Verbeke, A. 2004. A perspective on regional and global strategies of multinational enterprises. Journal of International Business Studies, 35(1): 3-18.

Rugman, A., \& Verbeke, A. 2005. Towards a theory of regional multinationals: A transaction cost economics approach. Management International Review, 45(1): 5-17.

Rugman, A., \& Verbeke, A. 2008a. A new perspective on the regional and global strategies of multinational services firms. Management International Review, 48(4): 397-411.

Rugman, A., \& Verbeke, A. 2008b. The theory and practice of regional strategy: $A$ response to Osegowitsch and 
Sammartino. Journal of International Business Studies, 39(2): 326-332.

Rugman, A. M., \& Verbeke, A. 2008c. A regional solution to the strategy and structure of multinationals. European Management Journal, 26(5): 305-313.

Schotter, A. P., Stallkamp, M., \& Pinkham, B. 2017. MNE headquarters disaggregation: The formation antecedents of regional management centers. Journal of Management Studies, 54(8): 1144-1169.

Verbeke, A., \& Asmussen, C. G. 2016. Global, local, or regional? The locus of MNE strategies. Journal of Management Studies, 53(6): 1051-1075.

Verbeke, A., Coeurderoy, R., \& Matt, T. 2018. The future of international business research on corporate globalization that never was.... Journal of International Business Studies, 49(9): $1101-1112$

Verbeke, A., \& Kano, L. 2016. An internalization theory perspective on the global and regional strategies of multinational enterprises. Journal of World Business, 51(1): 83-92.

Witt, M. A. 2019. De-globalization: Theories, predictions, and opportunities for international business research. Journal of International Business Studies, 50(7): 1053-1077.

Publisher's Note Springer Nature remains neutral with regard to jurisdictional claims in published maps and institutional affiliations. 